\section{Jacek Karasiński}

(iD) https://orcid.org/0000-0003-4326-5044

Department of the Financial Systems of the Economy

Faculty of Management

University of Warsaw, Poland

jkarasinski@wz.uw.edu.pl

\section{Patryk Zduńczak}

(iD) https://orcid.org/0000-0002-8520-4162

Faculty of Management

University of Warsaw, Poland

patryk.zdunczak@gmail.com

\title{
Do extreme market value ratios mean that the market is informationally inefficient? A study of the Warsaw Stock Exchange
}

Accepted by Editor Ewa Ziemba | Received: October 6, 2020 | Revised: January 30, 2021; May 13, 2021 | Accepted: May 20, 2021 | Published: June 28, 2021.

(C) 2021 Author(s). This article is licensed under the Creative Commons Attribution-NonCommercial 4.0 license (https://creativecommons.org/licenses/by-nc/4.0/)

\begin{abstract}
Aim/purpose - The aim of this paper is to verify whether extremely high values of market value ratios are the symptoms of informational inefficiency of the market in a weak form. The authors intend to examine whether these phenomena co-occur with each other. Design/methodology/approach - Following Bachelier's strict random walk model, we quantified a weak-form informational market efficiency with the use of the percentage of normality tests in stock returns run (Expanded Shapiro-Wilk, D'Agostino-Pearson and Jarque-Bera), which indicate that the analyzed distribution is normal (a null hypothesis cannot be rejected). The empirical study was based on the comparison of the market value ratios $(\mathrm{P} / \mathrm{E}$ and $\mathrm{P} / \mathrm{BV})$ and the informational efficiency measure at the level of particular companies, listed on the Main Market and NewConnect of the Warsaw Stock Exchange, and grouped into eight sectors. In order to do this, we analyzed scatterplots, descriptive statistics, Pearson's and Spearman's rank correlation coefficients. The dataset covered 214 companies (based on the assumptions made) in the period from 2016, December 31 to 2020, March 23.

Findings - Results obtained indicated that, in most cases, the extremely high values of market value ratios did not co-occur with market inefficiency. Hence, the outstandingly high market value ratios do not have to be the symptoms of market inefficiency.
\end{abstract}

Cite as: Karasiński, J., \& Zduńczak, P. (2021). Do extreme market value ratios mean that the market is informationally inefficient? A study of the Warsaw Stock Exchange. Journal of Economics \& Management, 43, 206-224. https://doi.org/10.22367/jem.2021.43.10 
Research implications/limitations - Following a common belief shared in the industry, but still not examined yet, this study examines the possible co-occurrence of extremely high market valuation and market inefficiency, but does not exploit it fully. The authors encourage other researchers, especially, to apply other market value ratios and to come up with their own ideas for market efficiency proxies. What is more, this study has been conducted on a relatively small market, thus the conclusions drawn from the study on the WSE should be tested on other, more developed markets.

Originality/value/contribution - According to the authors' knowledge, this study is one of the first trying to examine if the extremely high market value ratios are the symptoms of the informational inefficiency of the market.

Keywords: efficient market hypothesis, weak-form efficiency, market value ratios, stock markets, random walk.

JEL Classification: G10, G12, G14.

\section{Introduction}

Following the papers by Trevino \& Robertson (2002) and Sun (2012), the market value ratios used in this study, such as $\mathrm{P} / \mathrm{E}$ (Price/Earnings) and $\mathrm{P} / \mathrm{BV}$ (Price/Book Value), constitute a commonly applied base for assessing the market valuation of stocks. A market price, i.e., a numerator in the formulas of the simplest market value ratios, does not have to change proportionately to various items from the financial statements, i.e., a denominator, as a current market price reflects not the historical performance of the company, but the investors' expectations pertaining to the company's future performance. Nevertheless, rapid changes in market value ratios or their extreme values (especially the extremely high ones) attract the attention of the industry, researchers, and journalists. Especially, a widespread occurrence of outstandingly high market value ratios among many stocks at the same time becomes a hot topic in the media (Samson, 2020; Somerset Webb, 2017). Such a broad spread of the high market valuation of financial assets is commonly related with speculative bubbles (extremely high market valuation usually precedes a speculative bubble burst), which constitute a deviation from the market informational efficiency (Nofsinger, 2011).

The issued described constitute a motivation for making an attempt to examine whether extremely high values of market value ratios are the symptoms of informational inefficiency of the market in a weak form. We mostly focused on the extremely high values of the market value ratios as, in the case of the WSE, they deviate from the average more significantly than the extremely low ones, as portrayed in Figures 1 and 2 (Section 4). The extremely high values present highly positively skewed distributions of the $\mathrm{P} / \mathrm{E}$ and $\mathrm{P} / \mathrm{BV}$ ratios, respectively, based on this study's research sample. 
In the empirical study, we attempted to answer a question whether extremely high market value ratios and market informational inefficiency co-occur with each other. We propose a research hypothesis stating that the extremely high market valuation co-occurs with the market informational inefficiency. Following Bachelier's strict random walk model (Czekaj, 2014), we quantified a weakform informational market efficiency with the use of the percentage of normality tests in stock returns run (Expanded Shapiro-Wilk, D'Agostino-Pearson and Jarque-Bera), which indicate that the analyzed distribution is normal (a null hypothesis cannot be rejected). The model of Bachelier states that if the returns of financial assets are subject to the random walk, they have to be normally distributed (Czekaj, 2014). Despite its age and strictness, Bachelier's random walk model is still treated by many researchers as a synonym of the informational efficiency of the market in a weak form proposed by Fama (1970) and Jensen (1978). This is also a common way to test it under strict assumptions stating that the returns of securities are i.i.d. with a 0 expected value (Campbell, Lo, \& MacKinlay, 1997; Czekaj, 2014; Linton, 2019; Witkowska, Matuszewska-Janica, \& Kompa, 2012). The empirical study was based on the comparison of the market value ratios $(\mathrm{P} / \mathrm{E}$ and $\mathrm{P} / \mathrm{BV})$ and the informational efficiency measure, at the level of particular companies, listed on the Main Market and NewConnect of the Warsaw Stock Exchange, and grouped into eight sectors. In order to do this, we analyzed scatterplots, descriptive statistics, Pearson's and Spearman's rank correlation coefficients. The dataset covered 214 companies (based on assumptions made) in the period from 2016, December 31 to 2020, March 23.

The remainder of this paper is organized as follows. Section 2 of this paper is devoted to the review of the literature on testing the informational efficiency of stocks and indexes, as well as some aspects of the essence of the market value ratios of the listed companies. Section 3 describes the research methodology. Section 4 presents the empirical results. Section 5 concludes the paper.

\section{Literature review}

Testing the informational weak-form efficiency of the financial markets constitutes a willingly taken up issue in academic studies, especially with the well-developed and well-known testing tools, the easily available data necessary to perform the tests, as well as the great theoretical and practical implications they provide. For instance, Mensi, Tiwari, \& Al-Yahyaee (2019) argued that the knowledge on the level of informational efficiency of the market and its changes 
are necessary for policymakers, as they want to know if their reforms and regulations work and increase the market informational efficiency, making the markets immune to external shocks and increasing investors' confidence toward the markets. What is more, according to Lim \& Brooks (2011), studies on informational efficiency are so often replicated due to constantly changing factors affecting it. What is surprising is the fact that the majority of the issue-related studies are focused on answering a question whether the markets are informationally efficient, as the studies making an attempt to answer the question how the efficiency changes over time are in a minority (e.g., Abdmoulah, 2010; Arshad, Rizvi, Ghani, \& Duasa, 2016; Borges, 2010; Emerson, Hall, \& Zalewska-Mitura, 1997; Jefferis \& Smith, 2004, 2005; Samanta, 2004; Smith \& Dyakova, 2014; Zalewska-Mitura \& Hall, 1999). A common conclusion, which can be drawn from both groups of studies, is that the results are market- and method-dependent.

A similar ambiguity reigns among another interesting group of issue-related studies, namely those devoted to the assessment of the financial crisis's impact on the informational weak-form efficiency of the market. This regards the studies that pertain to the global financial crisis 2008 (e.g., Anagnostidis, Varsakelis, \& Emmanouilides, 2016; Katris \& Daskalak, 2013; Mensi, Tiwari, \& Yoon, 2017; Sensoy \& Tabak, 2015; Singh, Deepak, \& Kumar, 2015; Smith, 2012) and the Asian stock markets crisis in 1997-1998 (e.g., Cheong, Nor, \& Isa, 2007; Hoque, Kim, \& Pyun, 2007; Kian-Ping, Brooks, \& Kim, 2007; Kim \& Shamsuddin, 2006).

However, there is no unambiguity among the studies on the informational market weak-form efficiency devoted to the Polish capital market (e.g., Buła, 2014; Jamróz \& Kilon, 2015; Witkowska \& Żebrowska-Suchodolska, 2008; Żebrowska-Suchodolska \& Mentel, 2018).

Furthermore, market value ratios find application in the studies pertaining to the informational efficiency of the market in the weak form. They are mostly used to check whether they give any possibilities to forecast stock prices. If they do, the efficient market hypothesis can be rejected. Trevino \& Robertson (2002) proposed that $\mathrm{P} / \mathrm{E}$ and $\mathrm{P} / \mathrm{BV}$ ratios can be used to explain the US stock prices, especially in the long-term predictions. Sun (2012) came to similar conclusions in a study examining predicting features of the $\mathrm{P} / \mathrm{E}$ and $\mathrm{P} / \mathrm{BV}$ ratios and company size on the Australian stock market. Gupta \& Arora (2019) verified whether the most popular eleven market value ratios influence the stock price in the case of companies listed on the National Stock Exchange of India. The results showed that the high value of a few ratios (including $\mathrm{P} / \mathrm{E}$ and $\mathrm{P} / \mathrm{BV}$ ) had a significantly positive effect on the market price of shares in the period between 
2007 and 2017. Park (2020) used monthly stock market data from the period 1871-2020 to analyze how the P/E ratio was related to stock market performance in the future and whether mispricing can produce opportunities to time the stock market. The findings suggested that the P/E ratio may reflect both rational expectations of the investors and mispricing, which does not appear to be significant and systematic enough to produce clear market signals and opportunities. The author suggested basing an investment strategy on a business cycle, which appears to be lucrative. Arkan (2016) underlined the importance of financial ratios in predicting stock price trends based on the data from the Kuwait financial market. Statistical tests were performed for 15 companies that belonged to 3 sectors in the years 2005-2014, to show the statistical examination of the prediction power of 12 financial ratios. The obtained results suggested that some of them could give strong positive relationships with stock behavior and trends. He indicated P/E, EPS, ROA, and ROE as the most effective ones. These could be truly useful to make the right investment decisions.

\section{Research methodology}

The empirical study consisted of a few steps described below. Required data were collected from the Thomson Reuters Eikon database. The first step was to calculate the following market value ratios: $\mathrm{P} / \mathrm{E}$ (Price/Earnings) and $\mathrm{P} / \mathrm{BV}$ (Price/Book Value), for each company listed on both markets of the Warsaw Stock Exchange (WSE), i.e., Main Market and NewConnect. The selection of the market value ratios was based on the research by Trevino \& Robertson (2002), and Sun (2012). The first assumption was that the stocks taken under consideration had to be listed on both markets of the WSE at least since 2016, December 31. What is more, companies had to be active as of 2020, March 23, to ensure complete data in the research period from 2016, December 31 to 2020, March 23. On March 23, 2020, which was the date of the data collection, most financial reports for the fourth quarter of 2019 were still not available yet, and thus the results for the third quarter of 2019 were considered the last ones for which the market value ratios were calculated. The data collected from the Thomas Reuters Eikon database were used to calculate $\mathrm{P} / \mathrm{E}$ and $\mathrm{P} / \mathrm{BV}$ ratios as at the end of each quarter in the research period. All calculations required for the study were made in Microsoft Excel. P/E ratio was calculated dividing the closing stock price from the last trading session of each quarter by the accumulated earnings per share from the last four quarters, while the $\mathrm{P} / \mathrm{BV}$ ratio was calculat- 
ed dividing the closing stock price from the last trading session of each quarter by the average value of equity per share from the last four quarters. In the case of a negative denominator, the market value ratio was not calculated. Moreover, in the case of the lack of data in the Thomas Reuters Eikon database, which did not enable the researchers to calculate the market value ratios, for 3 of all 12 periods, the company was rejected from the sample. The final sample consisted of 214 companies.

The goal of the second step of the research was to run some normality tests (Expended Shapiro-Wilk, D'Agostino-Pearson and Jarque-Berra) based on daily logarithmic returns and to calculate the percentage of the normality tests performed, in which the null hypothesis could not be rejected, which was then used as a proxy for the informational market efficiency in a weak form. The null hypothesis assumed that the distribution of daily returns was normal. The normality tests mentioned above were performed for each stock in Microsoft Excel using The Real Statistics Resource Pack add-in. In all conducted tests, the output parameter was a p-value, i.e., test probability. The null hypothesis is rejected for the benefit of the alternative one, when the p-value resulting from the normality test is less than the significance level of $\alpha=0.05$. The alternative hypothesis states that the distribution of the empirical returns is not compatible with the normal distribution. Following Borowski $(2017,2018)$, the normality tests were conducted for daily logarithmic stock returns in 30,60, and 100-session rolling windows. When the test was conducted for the first window, the window moved by 1 session forward, up to the end of the research period. At this point, an additional assumption was made, stating that each test required at least $75 \%$ of the daily returns to be run (some data were missing). The second assumption related to this part of the study stated that when for a given company less than $90 \%$ of the tests possible to perform were conducted, a given company was rejected from the research sample. The average percentage of the null hypothesis which could not be rejected was calculated for each company. Following a widely applied and approved practice, the obtained results were compared within particular sectors.

\section{Empirical results}

Table 1 presents descriptive statistics pertaining to $\mathrm{P} / \mathrm{E}$ and $\mathrm{P} / \mathrm{BV}$ market value ratios of the companies divided into the WSE sectors. Distributions of the market value ratios in each sector are highly leptokurtic and positively skewed due to extremely high market value ratios. 
Table 1. Descriptive statistics pertaining to $\mathrm{P} / \mathrm{E}$ and $\mathrm{P} / \mathrm{BV}$ market value ratios of the companies divided into the WSE sectors

\begin{tabular}{|c|c|c|c|c|c|c|c|c|c|}
\hline \multirow{2}{*}{\multicolumn{2}{|c|}{ Statistics/ratio }} & \multicolumn{8}{|c|}{ Sector } \\
\hline & & \multirow{2}{*}{ 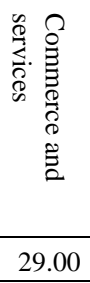 } & \multirow{2}{*}{ 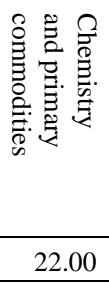 } & \multirow{2}{*}{ 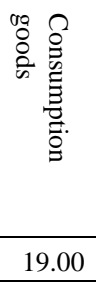 } & \multirow{2}{*}{ 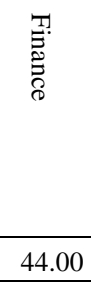 } & \multirow{2}{*}{ 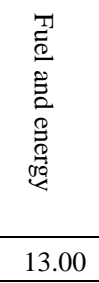 } & \multirow{2}{*}{ 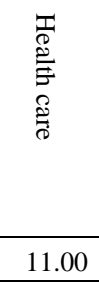 } & \multirow{2}{*}{ 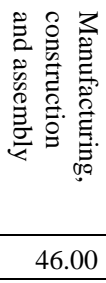 } & \multirow{2}{*}{ 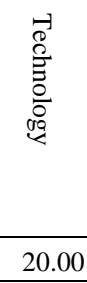 } \\
\hline Count & $\mathrm{P} / \mathrm{E}$ & & & & & & & & \\
\hline & $\mathrm{P} / \mathrm{BV}$ & 29.00 & 22.00 & 19.00 & 47.00 & 14.00 & 15.00 & 47.00 & 21.00 \\
\hline \multirow[t]{2}{*}{ Mean } & $\mathrm{P} / \mathrm{E}$ & 58.10 & 29.01 & 20.87 & 18.08 & 33.63 & 57.25 & 26.86 & 32.54 \\
\hline & $\mathrm{P} / \mathrm{BV}$ & 5.38 & 1.14 & 3.46 & 2.12 & 3.80 & 8.35 & 1.24 & 2.89 \\
\hline \multirow[t]{2}{*}{ Median } & $\mathrm{P} / \mathrm{E}$ & 26.57 & 12.37 & 16.34 & 12.03 & 10.29 & 16.93 & 12.79 & 16.66 \\
\hline & $\mathrm{P} / \mathrm{BV}$ & 3.69 & 1.10 & 2.06 & 1.23 & 0.84 & 2.21 & 0.93 & 1.31 \\
\hline \multirow[t]{2}{*}{ 1. Decile } & $\mathrm{P} / \mathrm{E}$ & 5.75 & 5.82 & 8.72 & 6.16 & 6.04 & 11.47 & 5.33 & 9.50 \\
\hline & $\mathrm{P} / \mathrm{BV}$ & 0.55 & 0.73 & 1.11 & 0.24 & 0.29 & 1.06 & 0.43 & 0.66 \\
\hline \multirow[t]{2}{*}{ 9. Decile } & $\mathrm{P} / \mathrm{E}$ & 122.35 & 28.51 & 41.78 & 30.80 & 58.51 & 63.24 & 60.82 & 44.88 \\
\hline & $\mathrm{P} / \mathrm{BV}$ & 12.41 & 1.56 & 4.40 & 3.07 & 9.83 & 3.96 & 2.03 & 3.41 \\
\hline \multirow[t]{2}{*}{ Min } & $\mathrm{P} / \mathrm{E}$ & 2.87 & 0.90 & 6.79 & 4.86 & 5.30 & 1.03 & 2.55 & 7.10 \\
\hline & $\mathrm{P} / \mathrm{BV}$ & 0.14 & 0.19 & 0.82 & 0.15 & 0.25 & 0.72 & 0.20 & 0.25 \\
\hline \multirow[t]{2}{*}{ Max } & $\mathrm{P} / \mathrm{E}$ & 424.59 & 280.13 & 59.52 & 167.01 & 251.41 & 367.15 & 178.81 & 210.08 \\
\hline & $\mathrm{P} / \mathrm{BV}$ & 25.70 & 2.55 & 24.97 & 29.23 & 29.55 & 94.51 & 5.97 & 23.90 \\
\hline \multirow[t]{2}{*}{ Skewness } & $\mathrm{P} / \mathrm{E}$ & 3.01 & 3.99 & 1.61 & 5.12 & 3.28 & 3.09 & 2.76 & 3.10 \\
\hline & $\mathrm{P} / \mathrm{BV}$ & 1.95 & 1.10 & 3.97 & 5.58 & 2.95 & 3.86 & 2.82 & 3.87 \\
\hline \multirow[t]{2}{*}{ Kurtosis } & $\mathrm{P} / \mathrm{E}$ & 10.16 & 16.67 & 2.10 & 29.71 & 11.10 & 9.89 & 7.46 & 9.59 \\
\hline & $\mathrm{P} / \mathrm{BV}$ & 3.92 & 1.90 & 16.49 & 34.36 & 8.90 & 14.93 & 9.32 & 15.97 \\
\hline
\end{tabular}

Source: Authors' own study.

Highly positive skewness of the market value ratios in each sector is confirmed by the arithmetic mean exceeding the median in each subsample. It should be emphasized that the case of highly positively skewed distributions pertaining to the whole research sample presented in Figures 1 and 2 (the skewness coefficients for the $\mathrm{P} / \mathrm{E}$ and $\mathrm{P} / \mathrm{BV}$ ratios were 4.23 and 8.66 , respectively), is not unique or accidental (for instance due to some exceptional companies or sectors), but it is a universal case for all sectors. 
Figure 1. Distribution of the stocks P/E ratios coming from this study's research sample

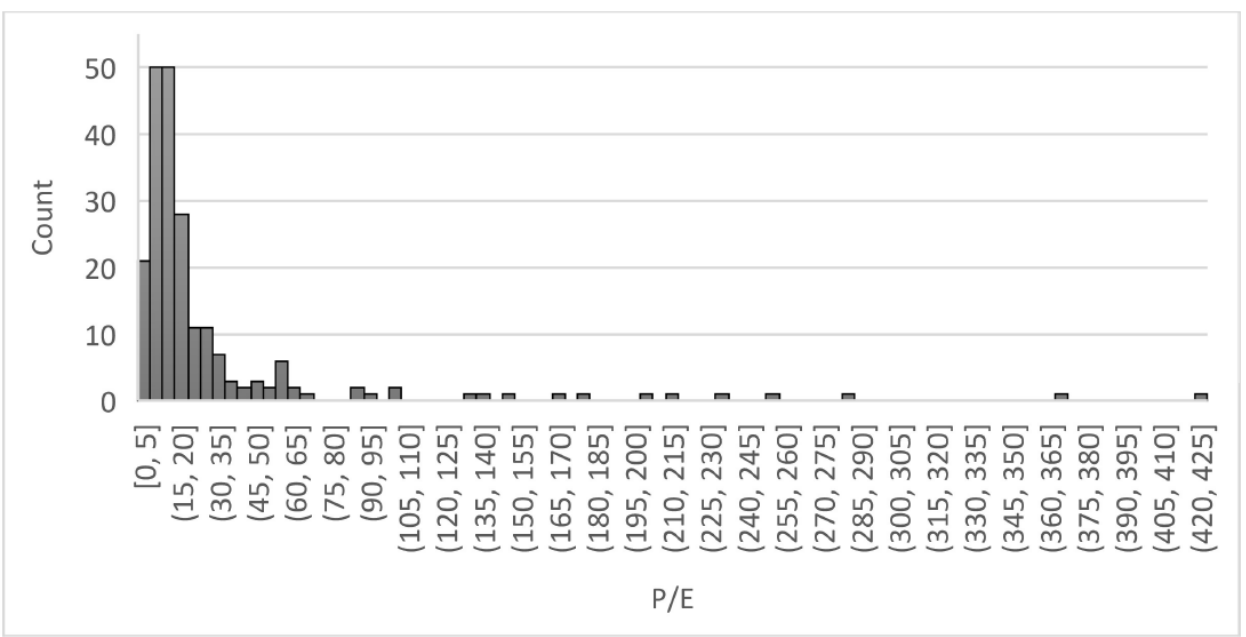

Source: Authors' own study.

Figure 2. Distribution of the stocks P/BV ratios coming from this study's research sample

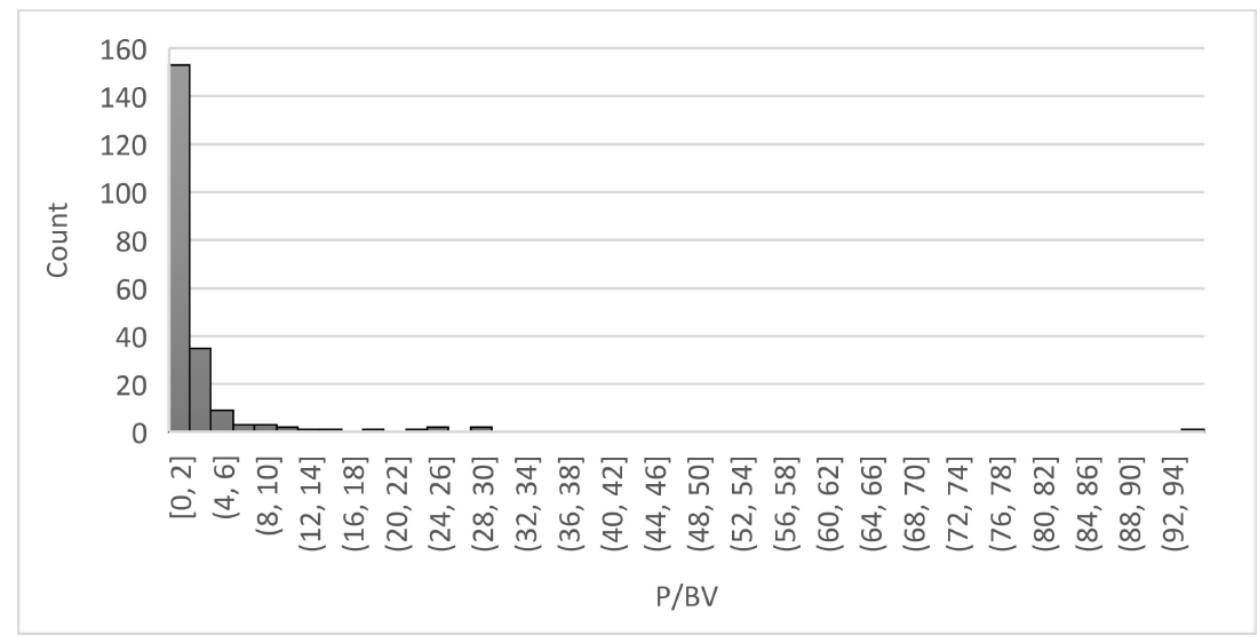

Source: Authors' own study.

Figure 3 constitutes a set of scatterplots presenting the average percentage of the null hypotheses, which could not be rejected in the stock return distribution normality test (weak-form informational market efficiency proxy on the $\mathrm{Y}$ axis), and the average $\mathrm{P} / \mathrm{E}$ ratio ( $\mathrm{X}$ axis), for each stock, in division to particular sectors of the WSE. Black points represent the results of particular companies, 
the white diamond refers to the average result of the sector, a single dashed green line (the one on the very left) pertains to the 1 st decile, a non-dashed line (the one in the middle) refers to the median, and a double dashed blue line represents the 9th decile. Based on the research hypothesis which states that the extremely high market valuation co-occurs with the market informational inefficiency, it is expected that the companies with outstandingly high $\mathrm{P} / \mathrm{E}$ ratios have also low (at least below the sector's average) weak-form informational market efficiency proxy. The highest $10 \%$ (above the 9th decile) and the lowest $10 \%$ (below the 1st decile) of the ratios, respectively, are treated as outstandingly high and low market value ratios.

Figure 3. A set of scatterplots presenting the average percentage of the null hypotheses, which could not be rejected in the stock return distribution normality test, and the average P/E ratio, for each stock, in division to particular sectors of the WSE

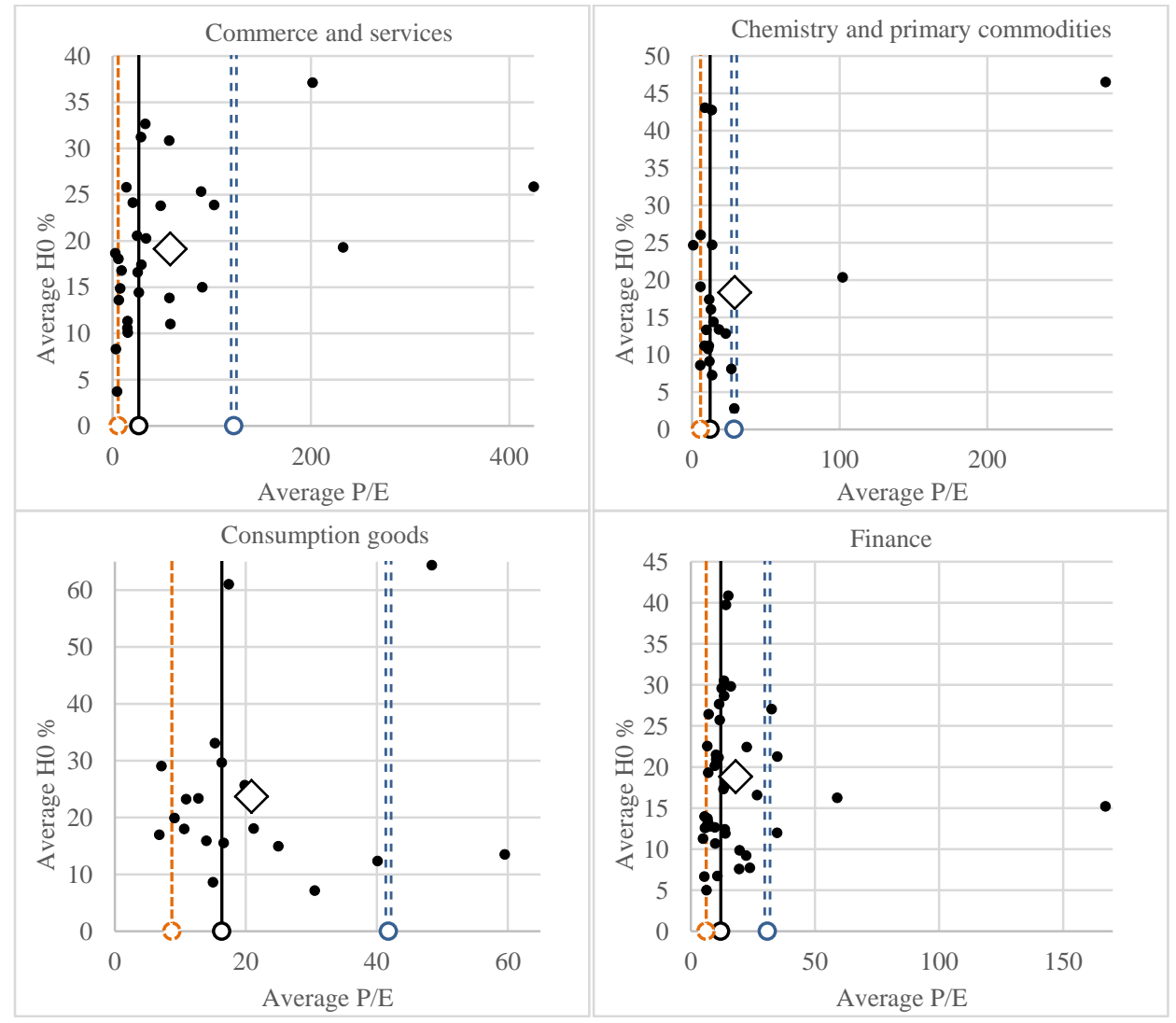




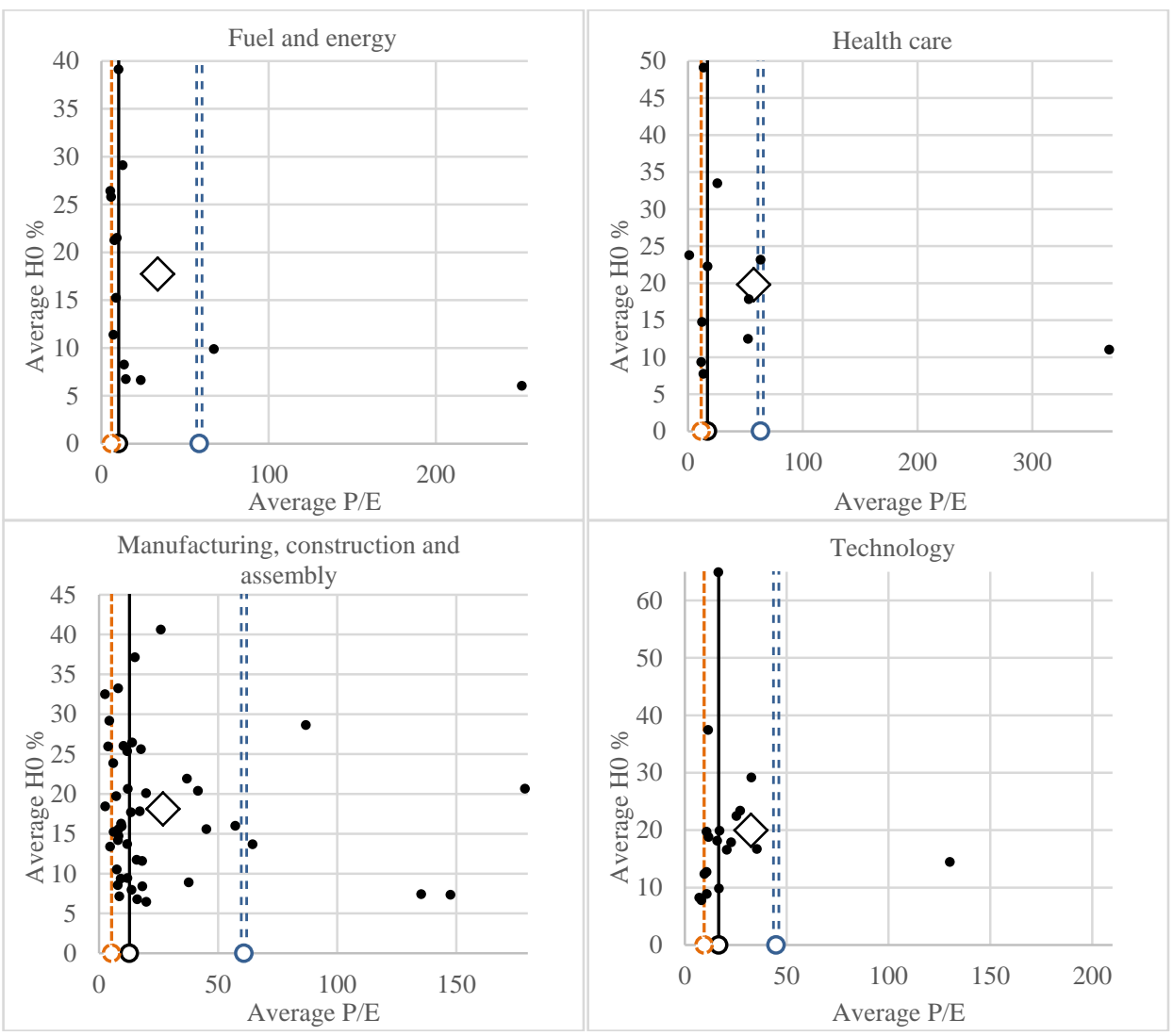

Source: Authors' own study.

Analysis of the scatterplots presented in Figure 3 does not deliver unbiased conclusions. An expected situation (the one in line with the research hypothesis), pertaining to the highest $10 \%$ of the $\mathrm{P} / \mathrm{E}$ ratios, can be observed in the case of 2 (fuel and energy, technology) out of 8 sectors (the companies have an informational efficiency proxy lower than the sector's average). An opposite situation to the expected one can be observed in the case of 2 (commerce and services, chemistry and primary commodities) out of 8 sectors. Mixed results can be observed for 4 (consumption goods, finance, health care, manufacturing, construction and assembly) out of 8 sectors. The analysis of the lowest $10 \%$ of $\mathrm{P} / \mathrm{E}$ ratios does not lead to unbiased conclusions. Analogical set of scatterplots to the one presented in Figure 3 has been prepared for the $\mathrm{P} / \mathrm{BV}$ ratio, and it is presented in Figure 4. 
Figure 4. A set of scatterplots presenting the average percentage of the null hypotheses, which could not be rejected in the stock return distribution normality test, and the average $\mathrm{P} / \mathrm{BV}$ ratio, for each stock, in division to particular sectors of the WSE
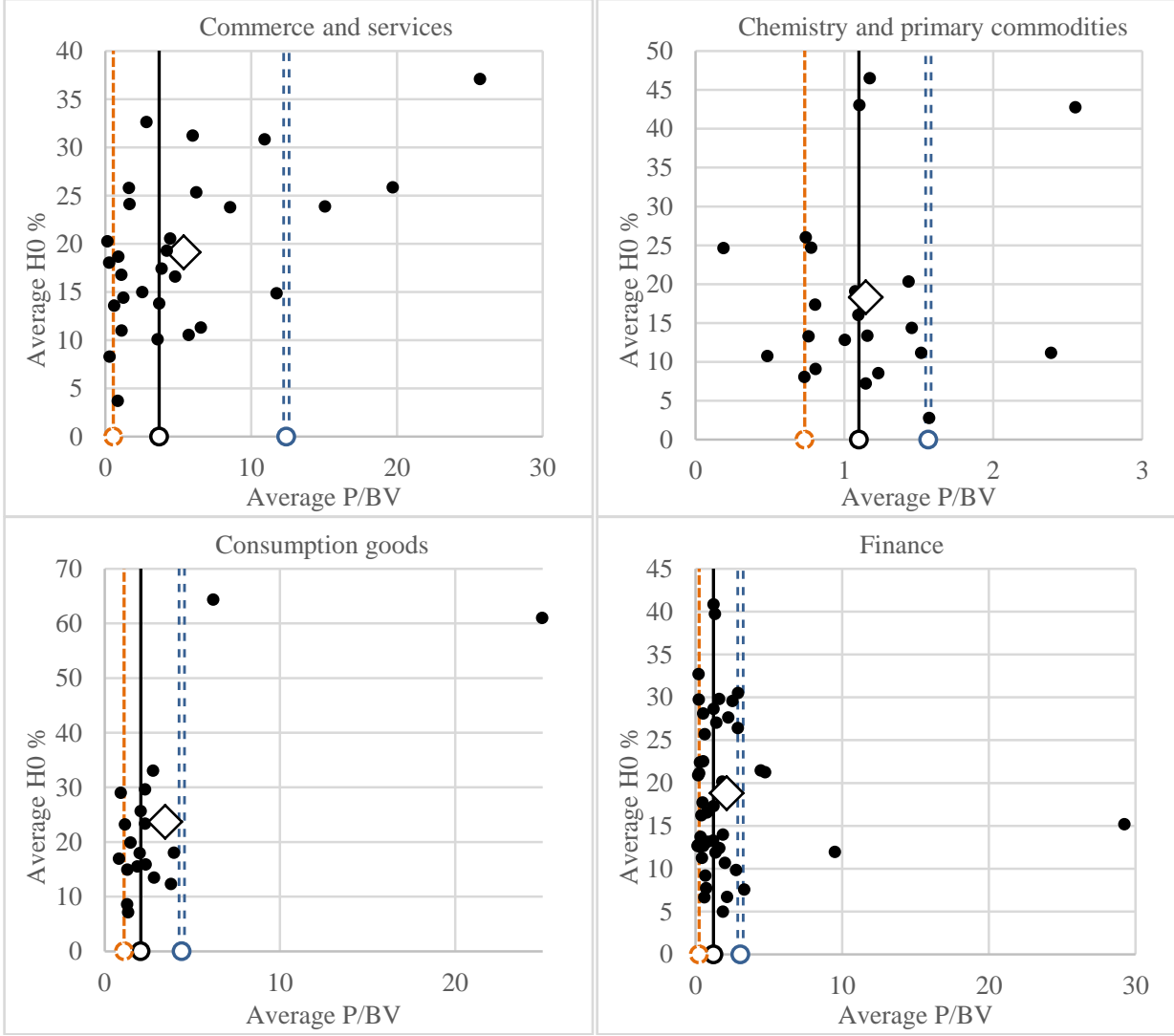


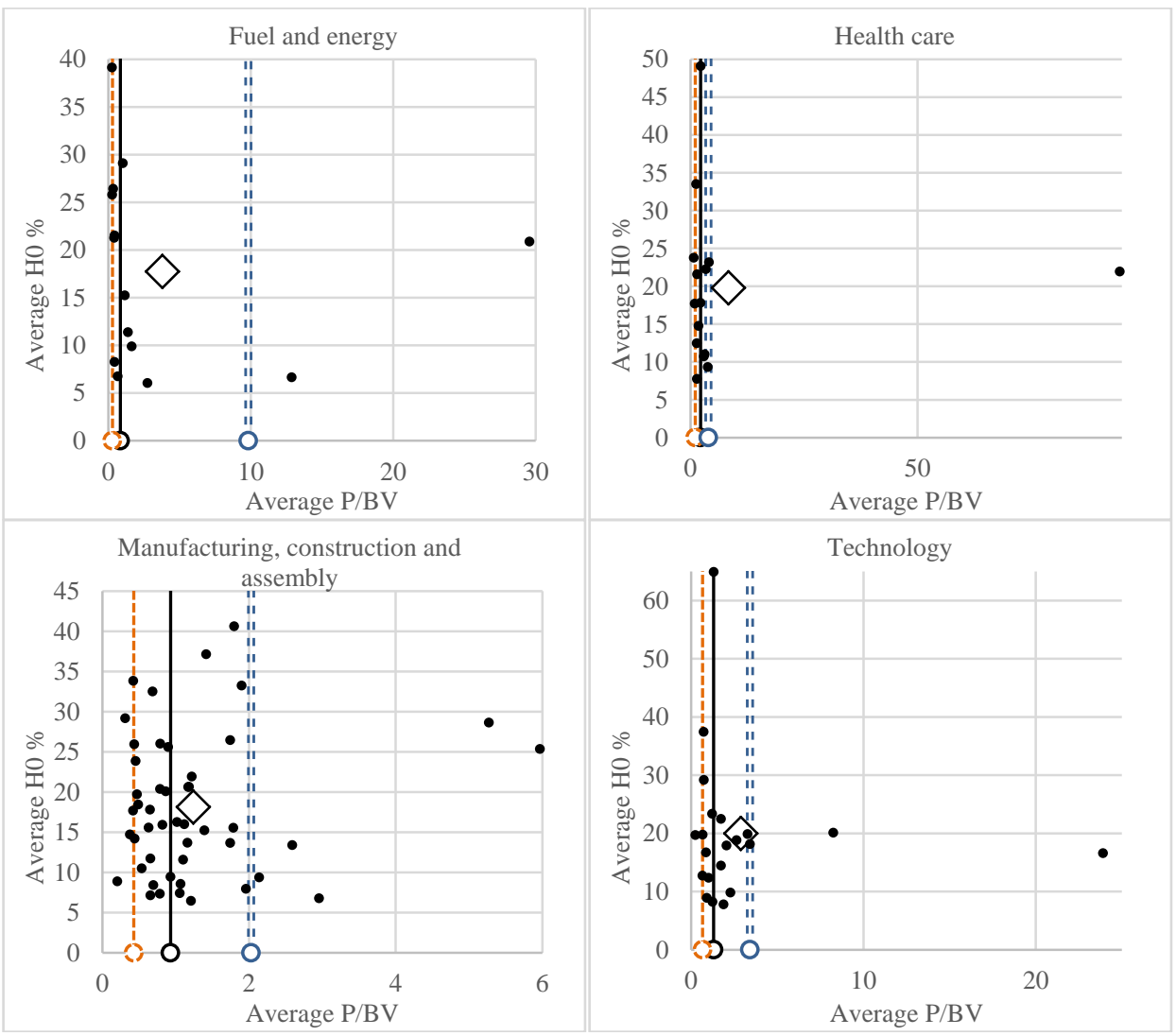

Source: Authors' own study.

The same as in the case of the $\mathrm{P} / \mathrm{E}$ ratio, the analysis of the scatterplots pertaining to the $\mathrm{P} / \mathrm{BV}$ ratio does not lead to unbiased results.

Table 2 presents the average values of the market value ratios and the informational market efficiency proxy for the $10 \%$ of the companies with the lowest and the highest market value ratios, as well as the middle $80 \%$ of the companies, divided into particular WSE sectors. Based on the research hypothesis, $10 \%$ of companies with the highest market value ratios should have the lowest average informational efficiency proxy. The middle $80 \%$ of the companies should have the highest average informational efficiency proxy. In the case of both the $\mathrm{P} / \mathrm{E}$ and the $\mathrm{P} / \mathrm{BV}$ ratio, this situation never happened. 
Table 2. The average values of the market value ratios and the informational market efficiency proxy for $10 \%$ of the companies with the lowest and the highest market value ratios, as well as the middle $80 \%$ of the companies, divided into particular WSE sectors

\begin{tabular}{|c|c|c|c|c|c|c|c|}
\hline \multirow[b]{3}{*}{ Sector } & \multirow{3}{*}{$\begin{array}{l}\text { Market value ratio/ } \\
\text { informational market } \\
\text { efficiency proxy }\end{array}$} & \multicolumn{6}{|c|}{ Average result } \\
\hline & & \multicolumn{3}{|c|}{$\mathrm{P} / \mathrm{E}$} & \multicolumn{3}{|c|}{$\mathrm{P} / \mathrm{BV}$} \\
\hline & & $\begin{array}{l}25 \\
0 \\
0 \\
0 \\
0 \\
0 \\
0 \\
\infty\end{array}$ & $\begin{array}{l}\infty \\
\stackrel{2}{2} \\
\stackrel{2}{2}\end{array}$ & 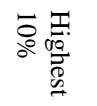 & 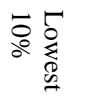 & 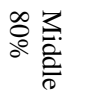 & 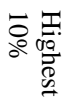 \\
\hline \multirow{2}{*}{$\begin{array}{l}\text { Commerce } \\
\text { and services }\end{array}$} & market value ratio & 3.70 & 35.44 & 286.26 & 0.23 & 4.12 & 20.16 \\
\hline & $\mathrm{H} 0 \%$ & 10.22 & 19.21 & 27.42 & 15.53 & 18.32 & 28.94 \\
\hline \multirow{2}{*}{$\begin{array}{l}\text { Chemistry } \\
\text { and primary } \\
\text { commodities }\end{array}$} & market value ratio & 4.12 & 13.44 & 136.95 & 0.47 & 1.08 & 2.17 \\
\hline & $\mathrm{H} 0 \%$ & 17.43 & 17.58 & 23.21 & 14.49 & 18.94 & 18.90 \\
\hline \multirow{2}{*}{$\begin{array}{l}\text { Consumption } \\
\text { goods }\end{array}$} & market value ratio & 6.95 & 18.31 & 53.97 & 0.87 & 2.18 & 15.58 \\
\hline & $\mathrm{H} 0 \%$ & 23.00 & 21.75 & 38.92 & 23.00 & 18.58 & 62.69 \\
\hline \multirow[t]{2}{*}{ Finance } & market value ratio & 5.52 & 12.93 & 65.62 & 0.19 & 1.29 & 10.25 \\
\hline & $\mathrm{H} 0 \%$ & 11.42 & 18.96 & 18.34 & 21.75 & 18.86 & 15.49 \\
\hline \multirow{2}{*}{$\begin{array}{l}\text { Fuel and } \\
\text { energy }\end{array}$} & market value ratio & 5.52 & 11.94 & 159.33 & 0.26 & 1.03 & 21.21 \\
\hline & $\mathrm{H} 0 \%$ & 26.11 & 17.69 & 7.97 & 32.47 & 15.58 & 13.76 \\
\hline \multirow[t]{2}{*}{ Health care } & market value ratio & 6.25 & 26.70 & 215.19 & 0.83 & 2.27 & 49.29 \\
\hline & $\mathrm{H} 0 \%$ & 16.56 & 22.52 & 17.09 & 20.75 & 19.12 & 22.55 \\
\hline \multirow{2}{*}{$\begin{array}{l}\text { Manufacturing, } \\
\text { construction } \\
\text { and assembly } \\
\end{array}$} & market value ratio & 3.60 & 16.80 & 122.59 & 0.35 & 1.02 & 3.78 \\
\hline & $\mathrm{H} 0 \%$ & 23.89 & 17.23 & 15.54 & 20.86 & 17.94 & 16.70 \\
\hline \multirow[t]{2}{*}{ Technology } & market value ratio & 7.65 & 18.46 & 170.12 & 0.52 & 1.57 & 11.85 \\
\hline & $\mathrm{H} 0 \%$ & 8.01 & 21.81 & 17.11 & 17.40 & 20.82 & 18.27 \\
\hline
\end{tabular}

Source: Authors' own study.

Table 3 presents Pearson's and Spearman's rank correlation coefficients, as well as their significance ( $\mathrm{p}$-values), calculated for pairs of variables as presented in Figures 3 and 4 . As the $\mathrm{P} / \mathrm{E}$ and $\mathrm{P} / \mathrm{BV}$ ratios are characterized by nonnormality, we have decided to include Spearman's rank correlation as one of the basic ways of dealing with the correlation of non-normally distributed data (Bishara \& Hittner, 2012). Based on our research hypothesis, and taking into account the highly positively skewed $\mathrm{P} / \mathrm{E}$ and $\mathrm{P} / \mathrm{BV}$ distributions, negative correlations were expected. Nevertheless, the correlation coefficients turned out to be very different across sectors, pairs of variables, and correlation coefficient types, ranging from highly negative to highly positive. The only sector with consistent results across pairs of variables and correlation coefficient types, i.e., moderately positive and significant correlation coefficients (assuming a significance level of 
$\alpha=0.05$ ), was commerce and services. The fuel and energy sector had similar, highly negative and significant Spearman's rank correlation coefficients for both pairs of variables. Received correlation coefficients do not indicate that there is any general (similar for all sectors) relation between the market value ratios and our informational efficiency measure.

Table 3. Pearson's and Spearman's rank correlation coefficients and their significance (p-values), calculated for pairs of variables as presented in Figures 3 and 4

\begin{tabular}{|c|c|c|c|c|c|c|c|c|}
\hline \multirow[b]{3}{*}{ Sector } & \multicolumn{8}{|c|}{ Pair of variables/coefficient/significance } \\
\hline & \multicolumn{4}{|c|}{$\mathrm{P} / \mathrm{E}-\mathrm{H} 0 \%$} & \multicolumn{4}{|c|}{$\mathrm{P} / \mathrm{BV}-\mathrm{H} 0 \%$} \\
\hline & 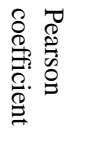 & 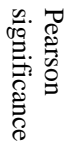 & 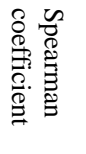 & 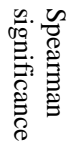 & 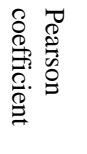 & 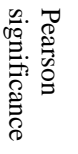 & 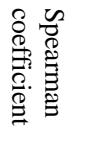 & 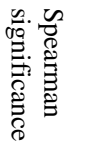 \\
\hline Commerce and services & 0.38 & 0.04 & 0.49 & 0.01 & 0.54 & 0.00 & 0.43 & 0.02 \\
\hline $\begin{array}{l}\text { Chemistry and primary } \\
\text { commodities }\end{array}$ & 0.47 & 0.03 & -0.10 & 0.67 & 0.13 & 0.56 & -0.06 & 0.80 \\
\hline Consumption goods & 0.10 & 0.68 & -0.20 & 0.41 & 0.69 & 0.00 & 0.32 & 0.18 \\
\hline Finance & -0.02 & 0.88 & 0.19 & 0.21 & -0.08 & 0.61 & -0.04 & 0.81 \\
\hline Fuel and energy & -0.41 & 0.17 & -0.65 & 0.02 & -0.09 & 0.77 & -0.67 & 0.01 \\
\hline Health care & -0.27 & 0.42 & 0.02 & 0.97 & 0.05 & 0.86 & -0.08 & 0.79 \\
\hline $\begin{array}{l}\text { Manufacturing, construc- } \\
\text { tion } \\
\text { and assembly }\end{array}$ & -0.12 & 0.41 & -0.15 & 0.30 & 0.14 & 0.35 & -0.02 & 0.88 \\
\hline Technology & -0.02 & 0.93 & 0.47 & 0.04 & -0.08 & 0.73 & -0.10 & 0.67 \\
\hline
\end{tabular}

Note: Significant coefficients (assuming a significance level of $\alpha=0.05$ ) have been indicated in grey.

Source: Authors' own study.

\section{Conclusions}

The conducted study provides biased results, which do not clearly indicate that the market value ratios' outstandingly high values co-occur with the weakform market informational efficiency. Thus, the outstandingly high market value ratios do not have to be the symptoms of market inefficiency. Hence, our research hypothesis has to be rejected.

Despite a commonly shared belief that outstandingly high market value ratios are the symptoms of speculative bubbles, which are a classic form of deviation from the efficient market hypothesis, this study suggests that the extremely high market value ratios do not have to mean that the investor's herd behavior is 
irrational. The construction of the most popular market value ratios is based on the current market price of the stock (numerator) and the historical data from the financial statements (denominator). The current market price depends on the expected performance of the company, not on the historical one. Thus, outstandingly high market value ratios can also be caused by very optimistic expectations of investors. Thus, paying too much attention to the basic and the most popular market value ratios may be misleading. One of the examples is CD Projekt, facing accusations of having too high market value ratios and being overpriced for many years (Torchała, 2020ab). Despite these accusations, the shares of CD Projekt have been in the upward trend for many last years. One of the most popular solutions to face the historical data overreliance of classic market value ratios is to estimate future financial data, and thus calculate forward market value ratios (Ghaeli, 2017).

Following a common belief that extremely high market value ratios are the symptoms of market informational inefficiency shared in the industry, but still not examined yet, this study introduced the issue of the possible co-occurrence of extremely high market valuation and market inefficiency, but did not exploit it fully. The authors encourage other researchers, especially, to apply other market value ratios and to come up with their own ideas for market efficiency proxies. The proxy for the weak-form informational market efficiency applied in this study was based on a strict Bachelier's random walk model. Thus, we additionally encourage other authors to base their market efficiency proxies on tests performed under more general conditions, better suited to actual distributions of stock returns, like the ones proposed by Campbell et al. (1997), and Linton (2019). What is more, this study was conducted on a relatively small market, thus the conclusions drawn from the study on the WSE should be tested on other, more developed markets.

According to the authors' knowledge, this study is one of the first trying to examine whether the extremely high market value ratios are the symptoms of the informational inefficiency of the market, what constitutes a unique value of this paper. This study may also prove of a great value to investors, who pay too much attention to the market value ratios, and who could resign from a possibly lucrative investment due to overly high market value ratios, thinking that their investment is overpriced. 


\section{References}

Abdmoulah, W. (2010, January). Testing the evolving efficiency of Arab stock markets. International Review of Financial Analysis, 19(1), 25-34. https://doi.org/10.1016/ j.irfa.2009.11.004

Anagnostidis, P., Varsakelis, C., \& Emmanouilides, C. J. (2016, April). Has the 2008 financial crisis affected stock market efficiency? The case of Eurozone. Physica A: Statistical Mechanics and its Applications, 447(1), 116-128. https://doi.org/ 10.1016/j.physa.2015.12.017

Arkan, T. (2016). The importance of financial ratios in predicting stock price trends: A case study in emerging markets. Finanse, Rynki Finansowe, Ubezpieczenia, 79, 13-26. https://doi.org/10.18276/frfu.2016.79-01

Arshad, S., Rizvi, S. A. R., Ghani, G. M., \& Duasa, J. (2016, January). Investigating stock market efficiency: A look at OIC member countries. Research in International Business and Finance, 36, 402-413. https://doi.org/10.1016/j.ribaf.2015.09.026

Bishara, A. J., \& Hittner, J. B. (2012). Testing the significance of a correlation with nonnormal data: Comparison of Pearson, Spearman, transformation, and resampling approaches. Psychological Methods, 17(3), 399-417. https://doi.org/ 10.1037/a0028087

Borges, M. R. (2010). Efficient market hypothesis in European stock markets. European Journal of Finance, 16(7), 711-726. https://doi.org/10.1080/1351847X.2010.495477

Borowski, K. (2017). Rozkład normalny stóp zwrotu z akcji wchodzących w skład następujących indeksów giełdowych: WIG20, MWIG40 i SWIG80 [normal distribution of returns of components of the following WSE Indexes: WIG20, MWIG40 and SWIG80]. Metody ilościowe badaniach ekonomicznych, XVIII/4, 541-560. https://doi.org/1 0.22630/MIBE.2017.18.4.50

Borowski, K. (2018). Normal distribution of returns of Warsaw Stock Exchange indexes. Management Issues, 2(74), 11-45. https://doi.org/10.7172/1644-9584.74.1

Buła, R. (2014). Efektywność informacyjna a zachowanie cen akcji tworzących indeks WIG20 [Behavior of WIG20 index components prices from efficient capital markets theorist viewpoint]. Studia Ekonomiczne / Uniwersytet Ekonomiczny w Katowicach. Inwestycje $i$ nieruchomości: wybrane zagadnienia, 177, 152-167. Retrieved from https://www.ue.katowice.pl/fileadmin/_migrated/content_uploads/ 11_R.Bula_Efektywnosc_informacyjna....pdf

Campbell, J. Y., Lo, A. W., \& MacKinlay, A. C. (1997). The econometrics of financial markets. Princeton, NJ: Princeton University Press.

Cheong, C. W., Nor, A. H. S. M., \& Isa, Z. (2007). Asymmetry and long-memory volatility: Some empirical evidence using GARCH. Physica A: Statistical and Theoretical Physics, 373(1), 651-664. https://doi.org/10.1016/j.physa.2006.05.050 
Czekaj, J. (2014). Efektywność gietdowego rynku akcji w Polsce z perspektywy $d w u d z i e s t o l e c i a$ [Efficiency of the stock market in Poland from the viewpoint of its twentieth anniversary]. Warszawa: Polskie Wydawnictwo Ekonomiczne.

Emerson, R., Hall, S. G., \& Zalewska-Mitura, A. (1997). Evolving market efficiency with an application to some Bulgarian shares. Economic Change and Restructuring, 30(2-3), 75-90. https://doi.org/10.1023/A:1003053807165

Fama, E. F. (1970). Efficient capital markets: A review of theory and empirical work. Journal of Finance, 25(2), 383-417. https://doi.org/10.2307/2325486

Ghaeli, M. R. (2017). Price-to-earnings ratio: A state-of-art review. Accounting, 3(2), 131-136. https://doi.org/10.5267/j.ac.2016.7.002

Gupta, H. K., \& Arora, M. (2019). Factors influencing stock price of manufacturing sector: An empirical analysis of NSE listed companies. Journal of The Gujarat Research Society, 21(11), 346-356. Retrieved from http:/gujaratresearchsociety.in/ index.php/JGRS/article/view/896

Hoque, H. A. A. B., Kim, J. H., \& Pyun, Ch. S. (2007). A comparison of variance ratio tests of random walk: A case of Asian emerging stock markets. International Review of Economics and Finance, 16(4), 488-502. https://doi.org/10.1016/j.iref. 2006.01.001

Jamróz, P., \& Kilon, J. (2015). Nie(efektywność) informacyjna giełdowego rynku kontraktów terminowych w Polsce [Informational (in)efficiency of the Polish futures market]. Zeszyty Naukowe Uniwersytetu Szczecińskiego. Finanse, Rynki Finansowe, Ubezpieczenia, 75, 193-204. https://doi.org/10.18276/frfu.2015.75-16

Jefferis, K., \& Smith, G. (2004). Capitalisation and weak-form efficiency in the JSE securities exchange. South African Journal of Economics, 72(4), 684-707. https:// doi.org/10.1111/j.1813-6982.2004.tb00130.x

Jefferis, K., \& Smith, G. (2005). The changing efficiency of African stock markets. South African Journal of Economics, 73(1), 54-67. https://doi.org/10.1111/j.18136982.2005.00004.x

Jensen, M. C. (1978, June-September). Some anomalous evidence regarding market efficiency. Journal of Financial Economics, 6(2-3), 95-101. https://doi.org/10.1016/ 0304-405X(78)90025-9

Katris, C., \& Daskalaki, S. (2013). Effect of economic crisis in efficiency and predictability of Greek and German stock indices. In Ch. C. Frangos (Ed.), Proceedings of the 3rd International Conference: Quantitative and Qualitative Methodologies in the Economic \& Administrative Sciences, QMEAS 2013 (pp. 224-230). Athens: TEI.

Kian-Ping, L., Brooks, R. D., \& Kim, J. H. (2007, June). Financial crisis and stock market efficiency: Empirical evidence from Asian countries. International Review of Financial Analysis, 17(3), 571-591. https://doi.org/10.1016/j.irfa.2007.03.001

Kim, J. H., \& Shamsuddin, A. (2008, June). Are Asian stock markets efficient? Evidence from new multiple variance ratio tests. Journal of Empirical Finance, 15(3), 518-532. https://doi.org/10.1016/j.jempfin.2007.07.001 
Lim, K. P., \& Brooks, R. (2011, February). The evolution of stock market efficiency over time: A survey of the empirical literature. Journal of Economic Surveys, 25(1), 69-108. https://doi.org/10.1111/j.1467-6419.2009.00611.x

Linton, O. (2019). Financial econometrics. Models and methods. Cambridge: Cambridge University Press. https://doi.org/10.1017/9781316819302

Mensi, W., Tiwari, A. K., \& Yoon, S. M. (2017, April). Global financial crisis and weak-form efficiency of Islamic sectoral stock markets: An MF-DFA analysis. Physica A: Statistical Mechanics and its Applications, 471(1), 135-146. https:// doi.org/10.1016/j.physa.2016.12.034

Mensi, W., Tiwari, A. K., \& Al-Yahyaee, K. H. (2019). An analysis of the weak form efficiency, multifractality and long memory of global, regional and European stock markets. The Quarterly Review of Economics and Finance, 72(C), 168-177. https:// doi.org/10.1016/j.qref.2018.12.001

Nofsinger, J. R. (2011). Psychologia inwestowania [The psychology of investing]. Gliwice: Helion.

Park, S. (2021, forthcoming November) The P-E ratio, the business cycle, and timing the stock market. Journal of Portfolio Management. https://doi.org/10.2139/ssrn. 3550705

Samanta, G. P. (2004). Evolving weak-form informational efficiency of Indian Stock Market. Journal of Quantitative Economics, 2(1), 66-75. https://doi.org/10.1007/ BF03404594

Samson, A. (2020, August 18). Investors increasingly unsettled by 'overvalued' markets. Financial Times. Retrieved from https://www.ft.com/content/cb7c1807-ba69-452696bb-30ffd189802a

Sensoy, A., \& Tabak, B. M. (2015, October). Time-varying long term memory in the European Union stock markets. Physica A: Statistical Mechanics and its Applications, 436, 147-158. https://doi.org/10.1016/j.physa.2015.05.034

Singh, P., Deepak, C. A., \& Kumar, A. (2015). Revisiting weak form efficiency of major equity markets in light of global financial crisis: A panel data approach. AsiaPacific Finance and Accounting Review, 3(1), 17-44. Retrieved from https://www.researchgate.net/profile/Arnav-Kumar-4/publication/287814716_ Revisiting_Weak_Form_Efficiency_of_Major_Equity_Markets_in_light_of_ Global_Financial_Crisis_A_Panel_Data_Approach/links/5679a13908aeaa48fa 4ac24f/Revisiting-Weak-Form-Efficiency-of-Major-Equity-Markets-in-light-ofGlobal-Financial-Crisis-A-Panel-Data-Approach.pdf

Smith, G. (2012). The changing and relative efficiency of European emerging stock markets. The European Journal of Finance, 18(8), 689-708. https://doi.org/10. 1080/1351847X.2011.628682

Smith, G., \& Dyakova, A. (2014). African stock markets: Efficiency and relative predictability. South African Journal of Economics, Economic Society of South Africa, 82(2), 258-275. https://doi.org/10.1111/saje.12009 
Somerset Webb, M. (2017, March 24). Stocks may stay overpriced for a while - but not forever. Financial Times. Retrieved from https://www.ft.com/content/62960bceOfe4-11e7-b030-768954394623

Sun, L. (2012). Information content of PE ratio, price-to-book ratio and firm size in predicting equity returns. In International Proceedings of Computer Science \& Information Tech (Vol. 36, pp. 275-281). Singapore: IACSIT Press. Retrieved from http://www.ipcsit.com/vol36/050-ICIIM2012-M10011.pdf

Torchała, A. (2020a). CD Projekt bańka czy okazja?? Kto ma rację? [Is CD Projekt a buble or an opportunity?] Retrieved from https://www.bankier.pl/wiadomosc/ CD-Projekt-banka-czy-okazja-Kto-ma-racje-7886410.html

Torchała, A. (2020b). Czytelnicy Bankier.pl: CD Projekt przewartościowany [Bankier.pl readers: CD Projekt is overvalued]. Retrieved from https://www.bankier.pl/ wiadomosc/Czytelnicy-Bankier-pl-CD-Projekt-przewartosciowany-7889773.html

Trevino, R., \& Robertson, F. (2002). P/E ratios and stock market returns. Journal of Financial Planning, 15(2), 76-84. Retrieved from https://www.proquest.com/ docview/217543865/fulltextPDF/6D972CA397AF47C1PQ/1?accountid=45580

Witkowska, D., \& Żebrowska-Suchodolska, D. (2008). Badanie efektywności GPW na przykładzie wybranych indeksów: test autokorelacji [Research of WSE efficiency based on selected indexes: Test of autocorrelation]. Acta Scientiarum Polonorum. Oeconomia, 7(4), 155-162.

Witkowska, D., Matuszewska-Janica, A., \& Kompa, K. (2012). Wprowadzenie do ekonometrii dynamicznej i finansowej [Introduction to dynamic and financial econometrics], Warszawa: Wydawnictwo SGGW.

Zalewska-Mitura, A., \& Hall, S. G. (1999, July). Examining the first stages of market performance: A test for evolving market efficiency. Economics Letters, 64(1), 1-12. https://doi.org/10.1016/S0165-1765(99)00074-9

Żebrowska-Suchodolska, D., \& Mentel, G. (2018). Testing market efficiency: Empirical investigation of Polish capital market. International Journal of Business and Society, 19(3), 699-708. Retrieved from http://www.ijbs.unimas.my/images/repository/ pdf/Vol19-no3-paper9.pdf 